\title{
Reliability analysis of a prestressed bridge beam designed in serviceability limit state as recommended by NBR 6118 and 7188
}

\section{Análise de confiabilidade de uma viga pré-moldada protendida de ponte dimensionada no estado limite de serviço preconizado na NBR 6118 e 7188}
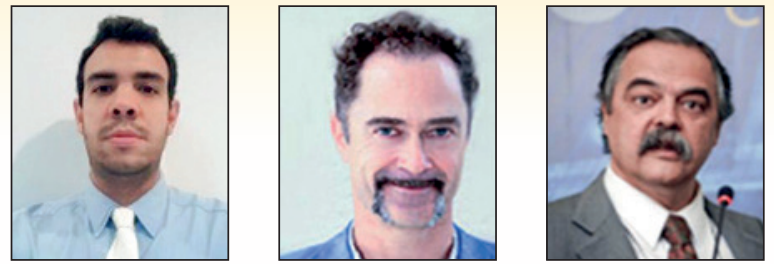

P. H. C. DE LYRA a pedro.lyra@maua.br https://orcid.org/0000-0001-5220-7343

A. T. BECK atbeck@sc.usp.br https://orcid.org/0000-0003-4127-5337

F. R. STUCCHI https://orcid.org/0000-0003-4149-0985

\begin{abstract}
Nowadays it is known that it is important to study the safety of structures to avoid tragic accidents or economic losses. The most widely used method in the world to evaluate the safety of structures is structural reliability. The reliability index of prestressed precast beams of bridges designed using Brazilian standards (NBR6118 and NBR7188) is not known. This work evaluates the annual reliability indexes of a prestressed precast beam bridge at the serviceability limit state (SLS) projected using the Brazilian standard and compares it with results from the literature. The studied bridge has 33.5 meters of span, is simply supported, constituted by five precast concrete beams with $U$ section. The reliability analysis was carried out using two methods for the four limit state equations: First Order Mean Value (FOMV) and First Order Reliability Method (FORM). Sensitivity analyzes were performed to consider both the relative contribution of these variables and the effect of their distributions on the annual reliability indexes for SLS. It was verified that the effect of load trains and the allowable stress significantly reduce the reliability index obtained for Brazilian standard. The service limit state equations are particularly sensitive to load trains, allowable stress and prestress losses, as well as their respective distributions.
\end{abstract}

Keywords: reliability, safety, precast beam, bridge, prestressed beam.

\section{Resumo}

Nos dias de hoje sabe-se que é importante estudar a segurança das estruturas, para evitar acidentes trágicos, bem como endereçar o compromisso entre segurança e economia. O método mais utilizado no mundo para avaliar a segurança de estruturas é a confiabilidade estrutural. O índice de confiabilidade não é conhecido para vigas pré-moldadas protendidas de pontes projetadas utilizando as normas brasileiras (NBR6118 e NBR7188). Este trabalho avalia os índices de confiabilidade anual de uma viga pré-moldada protendida de ponte no estado limite de serviço (ELS), projetada utilizando a norma brasileira, e compara com resultados da literatura. A ponte estudada possui 33,5 metros de vão, é bi apoiada, constituída por cinco vigas de concreto protendido com seção U. A análise de confiabilidade foi realizada utilizando dois métodos para as quatro equações do estado limite: "First Order Mean Value" (FOMV) e método de confiabilidade de primeira ordem (FORM). Análises de sensibilidades foram executadas para considerar tanto a contribuição relativa das variáveis envolvidas como o efeito de suas distribuições nos índices de confiabilidade anual para ELS. Verificou-se que o momento fletor do trem-tipo e as tensões admissíveis reduzem significativamente os índices de confiabilidade obtidos para a norma brasileira. As equações de estado limite de serviço são particularmente sensíveis ao momento fletor do trem-tipo, tensões admissíveis e perdas de protensão, bem como suas respectivas distribuições.

Palavras-chave: confiabilidade, segurança, concreto protendido, pontes, vigas protendidas. 


\section{Introduction}

A bridge is a construction meant to establish the continuation of a path going over an obstacle and is also an important component for transportation. Any failure that may come to block it causes significant hindrance, preventing people to proceed and causing economic losses. It is thus important to study the safety of these structures so that they can have a longer service life, without interruption, and at the lowest cost possible. The theory most widely used to assess structural safety, be it for serviceability limit states (SLS) or for ultimate limit states (ULS), is structural reliability. The reliability of a structure is associated to the confidence level the analyst has that it will meet its design purpose for a certain reference period.

The reliability method requires statistical characterization of the parameters involved in the model, which depends on the quality of the statistical data related to the problem and on the accuracy of the mathematical model used for describing the mechanical problem. In Brazil, use of reliability theory caused a significant change in the way structural elements, such as cantilever slabs and pillars, are designed. From the studies conducted by Stucchi and Santos [31] and [32], using the theory of reliability, all internal forces in 18 to $10-\mathrm{cm}$ cantilever slabs must be raised by a coefficient $\gamma_{n}$. Likewise, version 2014 of the standard NBR6118 limited the minimum size of pillars to $14 \mathrm{~cm}$, whereas previous versions accepted pillars starting at $12 \mathrm{~cm}$ in (minimum) thickness.

To help with the analysis of structural reliability, the concept of reliability index $\beta$ was introduced. Some standards, such as the Eurocodes and the Load and Resistance Factor Design of the United States, specify a target reliability index value, according to the importance of the structure or structural element.

\section{Calibration of the international standards for prestressed concrete bridges}

According to Portela[27], much effort has been made towards

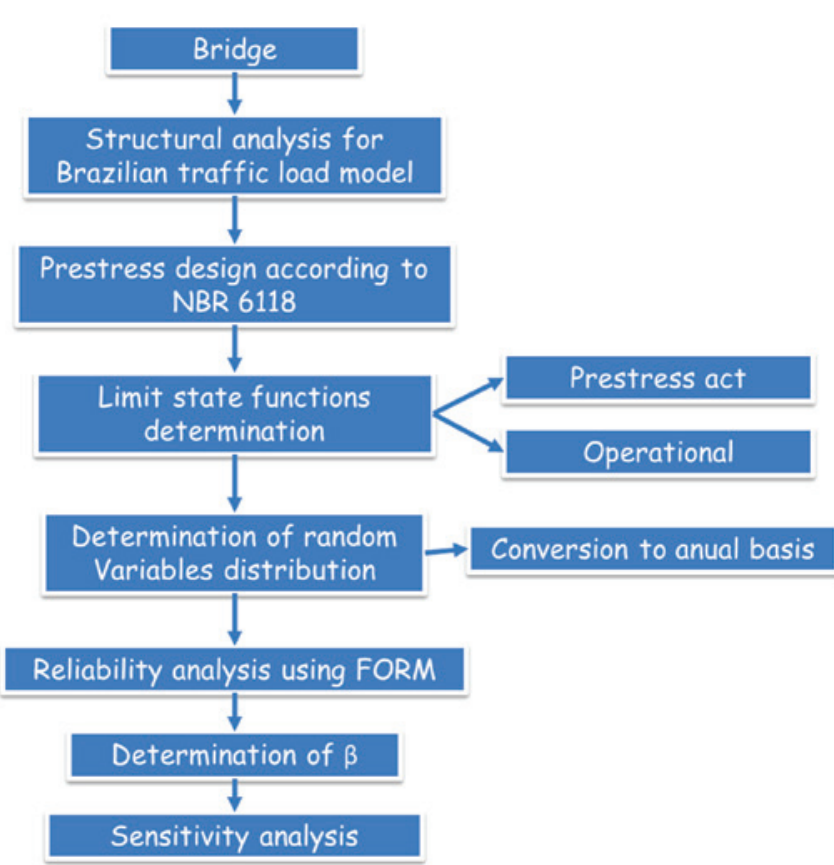

Figure 1

Methodology flowchart

determining the action model due to traffic. Special attention should be given to Nowak, Nassif and DeFrain [20], which used normal distributions to extrapolate the traffic load effect for 75 years.

In Brazil, an important work for determining the traffic load model was that by Stucchi and Luchi [30], who simulated the traffic in grid concrete bridges and in box girder section, with beams span varying between $30 \mathrm{~m}$ and $200 \mathrm{~m}$, in congestion situation, using data collected from road scale weighing using gumbel distribution and a return period of 140 years. In Europe, the analyses performed by O'Brien and Enright [25] and Sivakumar [29] used moving weighing to model load on bridges.

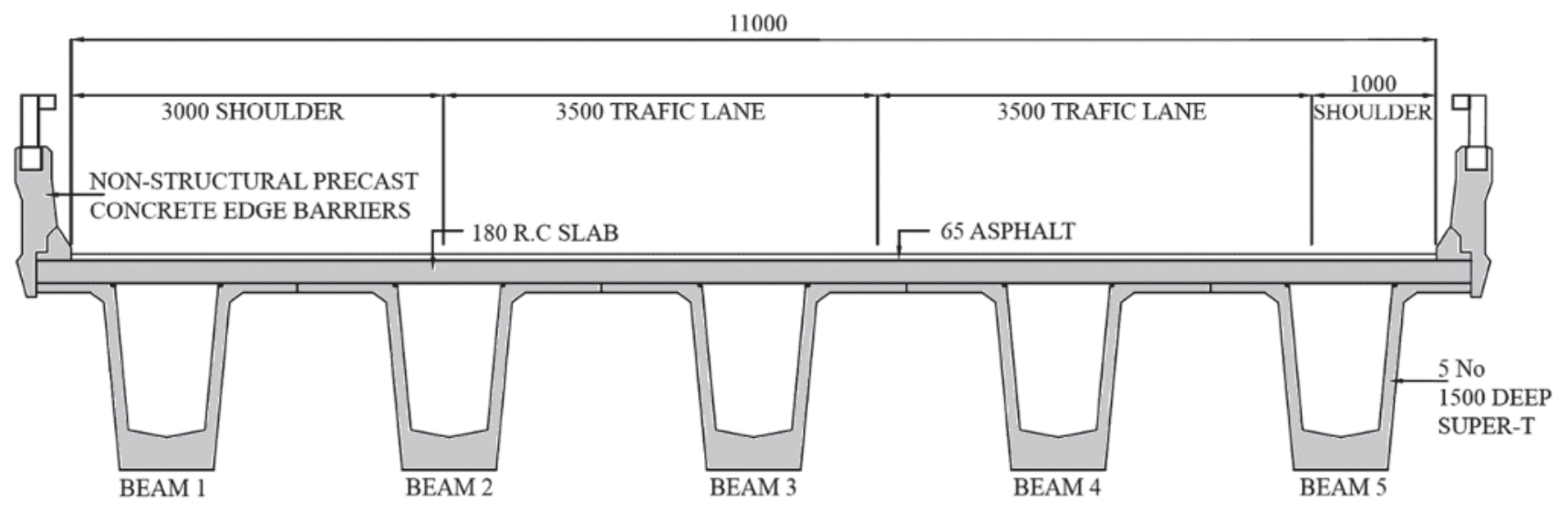

Figure 2

Bridge deck layout: Beams 1 and 5 have a $2100 \mathrm{~mm}$ top flange width, Beams 2 to 4 have a $2455 \mathrm{~mm}$ top flange width. All measurements are in mm (Caprani, Mayer e Siamphukdee[5]). Transversal beams only at support 

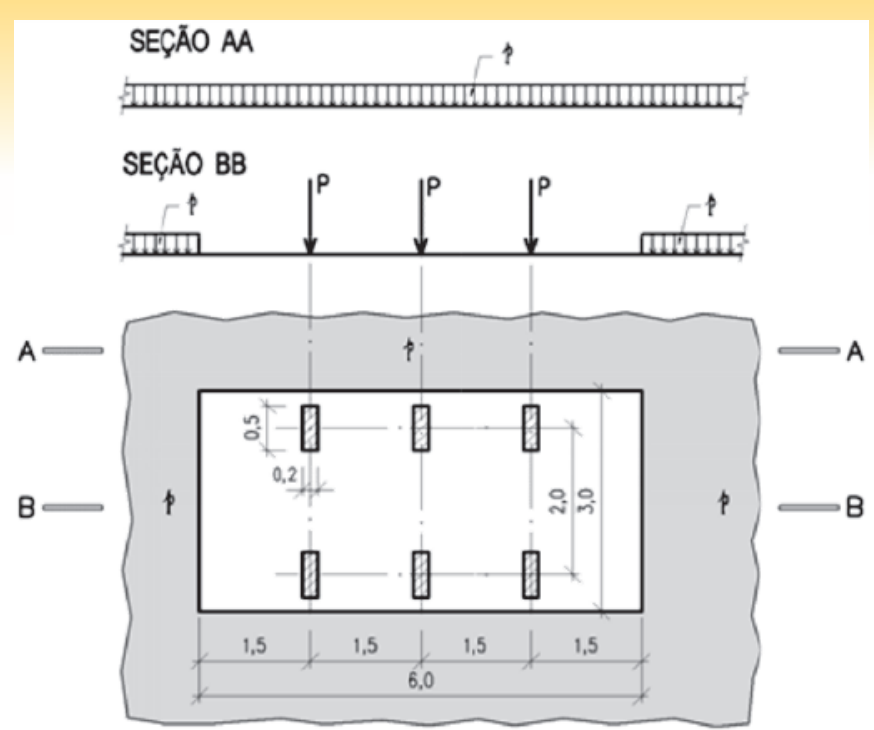

\section{Figure 3}

Traffic load model TB-450 from NBR7188-2013 Standard [3]

Furthermore, several works assess the reliability indexes for prestressed concrete (PC) beams and decks, according to certain international standards. One of the pioneering works is by Al-Harthy and Frangopol [1], who assessed 73 double cantilever beams of prestressed concrete, in their ultimate limit state (ULS) and serviceability limit state (SLS), based on the design and verifications established by the American Concrete Institute ( $\mathrm{ACl}$ ) standard.

Other studies include determining the reliability indexes in the ULS bending capacity and SLS admissible stresses during prestressing and operation for bridge precast prestressed beams for the Chinese standard, Hong Kong SDMRH and AASHTO LRFD (Du and $\mathrm{Au}[6]$ ).

Hwang, Nguyen and Nguyen [12] investigated the reliability indexes of bridge precast prestressed beams in SLS for the existing Korean traffic load model and a traffic load model recently proposed. The traffic load effect was assumed to be lognormally distributed. A more recent study by Caprani, Mayer and Siamphukdee [5] investigated the value of the reliability index for the Australian standard, using the European standard and a hybrid case as parameters for comparison.

\section{Methodology}

Figure 1 presents the methodology used herein, following Caprani, Mayer and Siamphukdee [5].

The reliability problem was solved using the StRAnD - "Structural Reliability Analysis and Design" software, Mathematica version, developed at the Structural Engineering Department of the São Carlos Engineering School by Prof. André Teófilo Beck.

\section{Bridge structural analysis and design}

The bridge studied, presented in Figure 2, is a simple support bridge with precast prestressed beams and slab cast "in situ", has $33.5-\mathrm{m}$ span, 5 precast prestressed beams, $18-\mathrm{cm}$ thick slabs cast "in situ" and a $6.5-\mathrm{cm}$ thick asphalt coating. The precast prestressed beam is $150-\mathrm{cm}$ high. Beam 1 was considered for analysis and design.

\subsection{Geometric characteristics and concrete strength}

The analysis and design of prestressing requires knowing the geometric characteristics and the concrete strength in two situations: during the prestressing and during operation of the bridge. At the moment of prestressing, a stage at which the beam is on the worksite, only the precast beam section resists the prestressing force and of its own weight; this occurs because the slab cast "in situ" has not yet been cast at this stage. In the bridge operation situation, the slab has already been concreted, being a part of the bridge strength system, which must support the beams and now the slab, pavement, barriers and traffic loads. Table 1 presents the geometric characteristics and the concrete strength for the two situations.

\subsection{NBR7188 - TB-450 traffic load model}

We here considered traffic load model TB-450 from NBR7188 [3] standard; this model is defined by a vehicle of $450 \mathrm{kN}$, with 6 wheels of $P=75 \mathrm{kN}$ of 3 load axes $1.5 \mathrm{~m}$ apart, occupying an $18 \mathrm{~m}^{2}$ area, surrounded by a constant, evenly distributed load $p=5 \mathrm{kN} /$ $\mathrm{m}^{2}$, according to Figure 3 .

Load "P" in kN is the concentrated static vertical load applied at the pavement level, with a characteristic value and without any increase. Load "p" in $\mathrm{kN} / \mathrm{m}^{2}$ is the evenly distributed static vertical load applied at pavement level, with a characteristic value.

The concentrated load " $Q$ " in $\mathrm{kN}$ and distributed load " $\mathrm{q}$ " in $\mathrm{kN} /$ $\mathrm{m}^{2}$ are the values of the vertical moving load applied at pavement level, equal to the characteristic values increased by the Vertical Impact Coefficients (VIC), the Number of Lanes (NoL) and of the Additional Impact (Al) coefficients, defined as follows.

$\mathrm{Q}=\mathrm{P}^{*} V I C^{*} N o L^{*} \mathrm{AI}$

$\mathrm{q}=\mathrm{p}^{*} V I C^{*} N o L^{*} \mathrm{AI}$

\subsection{Allowable stresses by NBR6118}

NBR6118[2] provides that, in case of lack of tests, the direct tensile

\section{Table 1}

Design (nominal) geometric and material properties of selected girder for design (Beam 1) at prestressing act and operation

\begin{tabular}{cccc}
\hline Data & Symbol (unity) & Prestressing act & Operation \\
\hline Concrete compressive strength & $\mathrm{f}_{\mathrm{ck}}\left(\mathrm{N} / \mathrm{mm}^{2}\right)$ & 50 & 65 \\
Gross area of section & $\mathrm{A}\left(\mathrm{mm}^{2}\right)$ & 556000 & 934000 \\
Inertia moment & $\mathrm{I}\left(\mathrm{mm}^{4}\right)$ & $159 \times 10^{9}$ & $348 \times 10^{9}$ \\
Elastic section modulus (bottom) & $\mathrm{W}_{\mathrm{i}}\left(\mathrm{mm}^{3}\right)$ & $235 \times 10^{6}$ & $332 \times 10^{6}$ \\
Elastic section modulus (top) & $\mathrm{W}_{\mathrm{s}}\left(\mathrm{mm}^{3}\right)$ & $193 \times 10^{6}$ & $549 \times 10^{6}$ \\
\hline
\end{tabular}


Table 2

Beam 1 maximum bending moments for different load components

\begin{tabular}{ccc}
\hline Load & Symbol & Brazilian standard \\
\hline Precast girder beam & $\mathrm{M}_{\text {pre }}$ & $2068 \mathrm{kN} . \mathrm{m}$ \\
Slab cast "in situ" & $\mathrm{M}_{\text {laje }}$ & $1362 \mathrm{kN} . \mathrm{m}$ \\
Asphalt + Barriers & $\mathrm{M}_{\mathrm{cp}}$ & $869 \mathrm{kN} . \mathrm{m}$ \\
Traffic loading & $\mathrm{M}_{\pi}$ & $3842 \mathrm{kN} . \mathrm{m}$ \\
\hline
\end{tabular}

strength can be assessed by its average or characteristic value by means of the following equations:

$f_{c t k, \text { inf }}=0.7 * f_{c t, m}$

$f_{c t k, s u f}=1.3 * f_{c t, m}$

For concretes of classes up to C50:

$f_{c t, m}=0.3 * f_{c k}^{2 / 3}$

For concretes from class C55 up to C90:

$f_{c t, m}=2.12 * \ln \left(1+0.11 * f_{c k}\right)$

where:

$\mathrm{f}_{\mathrm{ct,m}}$ and $\mathrm{f}_{\mathrm{ck}}$ are expressed in megapascal (MPa).

For the prestressing design, in an operation situation, it is considered that the maximum tensile stress cannot exceed:

$f_{c t, f}=\alpha * f_{c t k, i n f}$

and in the prestressing moment situation:

$f_{c t, f}=\alpha * f_{c t m, j}$

with $\alpha$ equal to 1.5 for rectangular sections, 1.2 for "T" type sections and 1.3 for "l" sections.

In the prestressing design, the maximum compressive stress during prestressing must be below $70 \%$ of the characteristic strength $f_{c k j}$, for the prestressing moment situation. For the maximum compressive stress at operation, the standard does not provide a value; yet a good practice is to adopt a value of about $60 \%$ of $f_{c k}$.

\subsection{Structural internal forces in beam 1}

The bridge was modeled in the commercial LIP software, supplied by TQS and developed by engineer Sander David Cardoso Junior. The software determines the structural internal forces in the girders for the permanent loads and the traffic load model, accord- ing to NBR7188 [3]. The analysis of transverse load distribution is performed by Fauchart method, respectively used for bridges provided by LIP. Table 2 presents the maximum bending moment at mid-span, obtained by the LIP software for each loading case.

\subsection{Design of beam 1 prestressing}

For the prestressing design, we used prestressed concrete level 3 (full prestressing) of standard NBR6118 [2]. The tendon used for prestressing is the same used in Caprani, Mayer and Siamphukdee [5], a tendon abiding by the specifications of the Australian standard AS 5100.5, as presented in Table 3. Table 4 presents the data used for the prestressing design and the result of the number of tendons.

\section{Reliability}

The design based on technical standards uses the limit state format, which approximately approaches the uncertainties in the design variables. Actually, the material, geometric and load effects are of random nature and can be described by probability distributions. A structure is considered reliable if it performs the function expected over the design life and an analysis of reliability provides the probability of failure and the reliability index:

$\beta=\Phi^{-1} \cdot\left(1-p_{f}\right)$

where $\Phi^{-1}$ is the inverse standard normal distribution function and $p_{f}$ is the probability of failure. The reliability index $(\beta)$ is here calculated using FORM. Details of FORM and analyses of reliability can be found in the literature (Melchers and Beck [18]).

\subsection{Limit state equations}

The limit state equations employed herein are presented as follows; two equations are for prestressing and two are for operation. Moment of prestressing:

\section{Table 3}

Design material properties of prestressing strands (AS 5100.5)

\begin{tabular}{ccccc}
\hline Strand & $\begin{array}{c}\text { Breaking strength } \\
\left(\mathrm{N} / \mathrm{mm}^{2}\right)\end{array}$ & $\begin{array}{c}\text { Jacking prestress } \\
\text { per strand } \\
(\mathrm{kN})\end{array}$ & $\begin{array}{c}\text { Modulus of elasticity } \\
(\mathrm{GPa})\end{array}$ & $\begin{array}{c}\text { Relaxation } \\
(\%)\end{array}$ \\
\hline $\begin{array}{c}\phi 15,2 \mathrm{~mm}-7 \text { wires - low } \\
\text { relaxation }\end{array}$ & 1750 & 188 & 195 & 2 \\
\hline
\end{tabular}

Table 4

Design results and the associated prestress losses

\begin{tabular}{ccc}
\hline Description & Symbol & Brazilian Standard \\
\hline Number of prestressing strands & - & 40 strands \\
Strand eccentricity & $e_{\mathrm{b}}$ & $545 \mathrm{~mm}$ \\
Total jacking prestress force & $\mathrm{P}_{0}$ & $7508 \mathrm{kN}$ \\
Immediate prestress losses & $\Delta \mathrm{P}_{\mathrm{i}}$ & $589 \mathrm{kN}$ \\
Long-term prestress losses & $\Delta \mathrm{P}_{\text {inf }}$ & $1430 \mathrm{kN}$ \\
\hline
\end{tabular}


$g_{1}(x)=-\sigma_{t, a t o}+\left[\left(P_{0}-\Delta P_{i}\right) \cdot\left(\frac{1}{A}-\frac{e_{b}}{W_{s, a t o}}\right)+\frac{M_{\text {pré }}}{W_{s, a t o}}\right]$

$g_{2}(x)=\sigma_{c, a t o}-\left[\left(P_{0}-\Delta P_{i}\right) \cdot\left(\frac{1}{A}+\frac{e_{b}}{W_{i, a t o}}\right)-\frac{M_{\text {pré }}}{W_{i, a t o}}\right]$

Operation:

$g_{3}(x)=\sigma_{c, \text { ope }}-\left[\left(P_{0}-\Delta P_{\text {inf }}\right) \cdot\left(\frac{1}{A}-\frac{e_{b}}{W_{s, a \text { ato }}}\right)+\frac{M_{\text {pré }}+M_{\text {laje }}}{W_{s, a t o}}+\frac{M_{c p}+M_{T T}}{W_{s, o p e}}\right]$

$g_{4}(x)=-\sigma_{t, o p e}+\left[\left(P_{0}-\Delta P_{\text {inf }}\right) \cdot\left(\frac{1}{A}+\frac{e_{b}}{W_{i, a t o}}\right)-\frac{M_{\text {pré }}+M_{\text {laje }}}{W_{i, a t o}}-\frac{M_{c p}+M_{T T}}{W_{i, o p e}}\right]$

where:

$\sigma_{\text {tato }}$ is the admissible tensile stress during prestressing;

$\sigma_{c, \text { ato }}$ is the admissible compressive stress during prestressing;

$\sigma_{t, o p e}$ is the admissible tensile stress at the operation;

$\sigma_{c, \text { ope }}$ is the admissible compressive stress at the operation;

$P_{0}$ is the initial prestressing force (jacking-up);

$\Delta \mathrm{P}_{\mathrm{i}}$ are the immediate losses of prestressing force;

$\Delta \mathrm{P}_{\text {inf }}$ are the total losses of prestressing force;

$A$ is the area of the cross section during prestressing;

$e_{b}$ is the eccentricity of the strand;

$\mathrm{W}_{\mathrm{i}, \text { ope }}$ is the bending resistance modulus of the lower fiber in operation;

$\mathrm{W}_{\mathrm{i}, \mathrm{i} \text { ato }}$ is the bending resistance modulus of the lower fiber during prestressing;

$W_{\text {s.ope }}$ is the bending resistance modulus of the upper fiber in operation; $\mathrm{W}_{\mathrm{s}, \text { ato }}$ is the bending resistance modulus of the upper fiber during prestressing;

$M_{\text {pré }}$ is the bending moment of the precast " $u$ " beam weight;

$M_{\text {laje }}^{\text {pre }}$ is the bending moment of the "in situ" cast slab weight;

$M_{c p}$ is the bending moment of the pavement weight plus the barriers;

$\mathrm{M}_{\mathrm{TT}}$ is the bending moment of the Brazilian traffic load model.

The first equation is for the tensile stress at the upper fiber, Limit State of Cracking (LS-C), and the second equation is for the compressive stress at the lower fiber, Excessive Compression Limit State (ECLS); both equations are used during prestressing. For these two situations, the immediate losses $\left(\Delta \mathrm{P}_{\mathrm{i}}\right)$ are considered to have already occurred. The third and fourth equation are for the tensile stress at the lower fiber, Limit State of Cracking (LS-C), and the compressive stress at the upper fiber, Excessive Compression Limit State (ECLS), respectively, in the operation situation, considering the total losses $\left(\Delta P_{\text {inf }}\right)$ for both equations. The limit state equations used in this study were the same as those used in Caprani, Mayer and Siamphukdee [5]. The consideration of creep adaptation results in different limit state equations.

\subsection{Conversion of the traffic load model value into annual exceedance probability}

The characteristic values of traffic load model type TB-450, presented

\section{Table 5}

Conversation traffic load model to annual basis

\begin{tabular}{cc}
\cline { 2 - 2 } & Brazilian standard \\
\hline Probability of annual failure & $0.7 \%$ \\
Coefficient of variation & 0.18 \\
$s_{p}=-\ln (-\ln (1-p))$ & 4.958334879 \\
$r=\frac{\theta}{u}=\left(\frac{\pi}{\operatorname{CoV} \cdot \sqrt{6}}-\gamma\right)$ & 0.152716595 \\
$\gamma$ & 0.5772 \\
$\lambda=\frac{1+r \cdot s_{p}}{1+r \cdot \gamma}$ & 1.615 \\
\hline
\end{tabular}

in NBR7188[3], correspond to values having $25 \%$ to $35 \%$ probability of being exceeded in an unfavorable sense, over a 50 -year period. If we consider the value of $30 \%$ probability of being exceeded over a 50 -year period, which corresponds to an average return period of 140 years, the probability converted into annual becomes:

$p=\frac{n}{T}=\frac{1}{140}=0.7 \%$

So that this study could be compared to Caprani, Mayer and Siamphukdee [5], we have to convert the action model value into annual exceedance probability. For the conversion, the maximum moment due to the traffic loading is considered to follow a type-1 Gumbel distribution, as presented by Obrien et al. [24] and and Stucchi and Luchi [30], and the value of the coefficient of variation (CV) is 0.18 , as presented in Rakoczy and Nowak [28]. The cumulative probability density function of a type-1 Gumbel distribution is:

$F(x)=\exp \left[-e^{\left.-\left(\frac{x-u}{\theta}\right)\right]}-\infty \leq x \leq \infty\right.$

where:

$\mathrm{x}$ is the random variable;

$\mathrm{u}$ is the location parameter;

$\theta$ is the scale parameter.

The standard deviation $(\sigma)$ for the type-1 Gumbel distribution becomes: $\sigma=\frac{\theta \cdot \pi}{\sqrt{6}}$

The bias factor is the ratio between the average value $(\mu)$ and the characteristic value $\left(\mathrm{x}_{\mathrm{p}}\right)$ and is presented in Equation 17.

$\lambda=\frac{x_{p}}{\mu}=\frac{u+\theta \cdot s_{p}}{u+\theta \cdot \gamma}$

where:

$\gamma$ is the Euler-Mascheroni constant, which has a value of 0.577216; $\mathrm{S}_{\mathrm{p}}$ is the "standard extremal variate" and is defined by equation 18.

$s_{p}=-\ln (-\ln (1-p))$

The coefficient of variation is defined as:

$C V=\frac{\theta \cdot \pi / \sqrt{6}}{u+\theta \cdot \gamma}$

When the values of parameters $u$ and $\theta$ of the gumbel distribution are unknown, as is our case, the ratio between them, called $r$, is used and is expressed as (Capriani Mayer and Siamphukdee [5]):

$r=\frac{\theta}{u}=\left(\frac{\pi}{C V \cdot \sqrt{6}}-\gamma\right)$

Therefore, the bias factor value, given only coefficient of variation (CV) and the exceedance probability ( $p)$, can be obtained by equation 21.

$\lambda^{*}=\frac{1+r \cdot s_{p}}{1+r \cdot \gamma}$

Table 5 presents the conversion of the value of the moment obtained by TB-450 into annual exceedance probabilities. Use of the maximum distribution in the analysis of serviceability limit state, for the bending moment from traffic load model, is conservative.

The bias factor $\left(\lambda^{*}\right)$, presented in equation 21 , makes two conversions: the first is the conversion of the characteristic moment of the 50-year distribution $\left(\mathrm{M}_{\mathrm{TT}}\right)$ to the characteristic moment of the annual distribution $\left(\mathrm{M}_{\text {TT,anual }}\right)$ and the second is the conversion of the characteristic value to the mean of the distribution, as presented in equation 22 .

$\mu_{M_{T T}}=\lambda^{*} \cdot M_{T T}=b_{f}, c_{t}, M_{T T}=b_{f} \cdot M_{T T, \text { anual }}$

$b_{f}$ is the coefficient that converts the characteristic value to the mean of the distribution; 
Table 6

Distributions for the random variables used in the reliability analysis

\begin{tabular}{|c|c|c|c|c|c|c|c|c|}
\hline R.V. & Unity & Distribution & $\lambda$ & Value & $\mu$ & CV & $\sigma$ & Reference \\
\hline$\sigma_{c, \text { ato }}$ & $\mathrm{N} / \mathrm{mm}^{2}$ & Normal & 1.28 & 30.0 & 38.4 & 0.164 & 6.2976 & $\begin{array}{c}\text { (Hueste et al.[1 1 ] ); } \\
\text { (Bartlett and MacGregor[4]) }\end{array}$ \\
\hline$\sigma_{\mathrm{c}, \mathrm{ope}}$ & $\mathrm{N} / \mathrm{mm}^{2}$ & Normal & 1.13 & 39.0 & 44.07 & 0.164 & 7.2275 & $\begin{array}{c}\text { (Hueste et al.[11 ]); } \\
\text { (Bartlett and MacGregor[4]) }\end{array}$ \\
\hline$\sigma_{\mathrm{t}, \text { ato }}$ & $\mathrm{N} / \mathrm{mm}^{2}$ & Normal & 1.03 & -4.0716 & -4.1938 & 0.183 & 0.7675 & $\begin{array}{c}\text { (Hueste et al.[1 1 ] ); } \\
\text { (Bartlett and MacGregor[4]) }\end{array}$ \\
\hline$\sigma_{t, \text { ope }}$ & $\mathrm{N} / \mathrm{mm}^{2}$ & Normal & 1.01 & -4.4478 & -4.4923 & 0.183 & 0.8221 & $\begin{array}{c}\text { (Hueste et al.[11 ]); } \\
\text { (Bartlett and MacGregor[4]) }\end{array}$ \\
\hline$P_{0}$ & $\mathrm{~N}$ & Normal & 1 & 7508000 & 7058000 & 0.015 & 112620 & (Caprani. Mayer and Siamphukdee[5]) \\
\hline$e_{b}$ & $\mathrm{~mm}$ & Normal & 1 & 545 & 545 & 0.015 & 8.175 & (Caprani. Mayer and Siamphukdee[5]) \\
\hline A & $\mathrm{mm}^{2}$ & Normal & 1 & 556000 & 556000 & 0.025 & 13900 & (Caprani. Mayer and Siamphukdee[5]) \\
\hline$W_{i, \text { ato }}$ & $\mathrm{mm}^{3}$ & Normal & 1 & 235000000 & 235000000 & 0.039 & 9165000 & (Caprani. Mayer and Siamphukdee[5]) \\
\hline$W_{s, \text { ato }}$ & $\mathrm{mm}^{3}$ & Normal & 1 & 193000000 & 193000000 & 0.038 & 7334000 & (Caprani. Mayer and Siamphukdee[5]) \\
\hline$W_{i, \text { ope }}$ & $\mathrm{mm}^{3}$ & Normal & 1 & 332000000 & 332000000 & 0.044 & $1.5 \mathrm{E}+07$ & (Caprani. Mayer and Siamphukdee[5]) \\
\hline$W_{\text {s.ope }}$ & $\mathrm{mm}^{3}$ & Normal & 1 & 549000000 & 549000000 & 0.073 & $4 \mathrm{E}+07$ & (Caprani. Mayer and Siamphukdee[5]) \\
\hline$\Delta \mathrm{P}_{\mathrm{i}}$ & $\mathrm{N}$ & Normal & 1 & 525560 & 525560 & 0.3 & 157668 & $(J C S S[13])$ \\
\hline$\Delta \mathrm{P}_{\text {inf }}$ & $\mathrm{N}$ & Normal & 1 & 1351440 & 1351440 & 0.3 & 405432 & $(\mathrm{JCSS}[13])$ \\
\hline$M_{\text {pre }}$ & N.mm & Normal & 1.03 & 2068000000 & 2007766990 & 0.08 & $1.6 \mathrm{E}+08$ & (Rakoczy and Nowak[28]) \\
\hline$M_{\text {laje }}$ & N.mm & Normal & 1.05 & 1362000000 & 1297142857 & 0.1 & $1.3 \mathrm{E}+08$ & (Rakoczy and Nowak[28]) \\
\hline$M_{c p}$ & N.mm & Normal & 1 & 869000000 & 869000000 & 0.25 & $2.2 \mathrm{E}+08$ & (Rakoczy and Nowak[28]) \\
\hline $\mathrm{M}_{\pi}$ & N.mm & Gumbel 1 & 1.615 & 3842000000 & 2379135588 & 0.18 & $4.3 \mathrm{E}+08$ & This paper; (Rakoczy and Nowak[28]) \\
\hline
\end{tabular}

$\mathrm{C}_{\mathrm{t}}$ is the coefficient that converts the characteristic bending moment of the 50-year distribution $\left(\mathrm{M}_{\mathrm{TT}}\right)$ to the characteristic bending moment of the annual distribution $\left(\mathrm{M}_{\mathrm{TT} \text {,anual }}\right)$.

\subsection{Distribution and value of the random variable of loss of prestressing}

For this study, the bridge was considered to be in an environment with an $15^{\circ} \mathrm{C}$ annual average temperature and a $60 \%$ average relative humidity $(\mathrm{RH})$.

There are only few studies on immediate and slow losses in prestressed concrete using probabilistic analysis. The study by Gilbertson and Ahlborn [10] presented the effects of the inherent variability of the parameters used to estimate the loss of prestressing. Two typical cases of prestressed beams of bridges were studied using the methods provided in AASHTO, $\mathrm{PCl}$ and $\mathrm{ACl} 318-99$ regarding loss of prestressing in operation condition.

As there is no study for the formulations proposed by NBR6118 [2], the JCSS study [14] was considered, taking into account a normal distribution, with a bias factor $(\lambda)$ equal to 1 and a coefficient of variation (CV) equal to 0.30 for the immediate and total losses already converted into annual probabilities.

\subsection{Distribution and values of the random variables}

Table 6 presents the random variables, type of distribution, average and coefficient of variance.

\section{Results and discussions}

\subsection{Reliability index}

Table 7 provides the results of the annual reliability index using the First-Order Mean Value (FOMV) method, First-Order Reliability Method (FORM) and the probability of failure (pf), for each limit state equation.

The reliability index obtained by the FOMV method yields some different values from the reliability index obtained by FORM. This difference exists because the FOMV method consists in a first-order approximation at the mean point, and FORM involves building a joint probability distribution function and its transformation into the standard normal space.

Since we used the same geometric characteristics and materials of the bridge presented in Caprani, Mayer and Siamphukdee [5], we can make a comparison of the annual reliability indexes. Table 8 presents the comparison of the annual reliability indexes, obtained

\section{Table 7}

Annual serviceability reliability indices for the four limit state functions

\begin{tabular}{|c|c|c|c|c|}
\hline & $g_{1}(x)$ & $g_{2}(x)$ & $g_{3}(x)$ & $g_{4}(x)$ \\
\hline$\beta_{\mathrm{FOMV}}$ & 5.57 & 2.84 & 3.70 & 2.29 \\
\hline$\beta$ by FORM & 5.53 & 2.84 & 3.71 & 2.26 \\
\hline$p_{f}$ by FORM & $1.6 \times 10-8$ & $2.26 \times 10-3$ & $5.59 \times 10-4$ & $1.19 \times 10-2$ \\
\hline
\end{tabular}




\section{Table 8}

Annual serviceability reliability indices for the four limit state functions from Australian, Europe and Brazilian Standard

\begin{tabular}{cccc}
\hline & AS $^{(1)}$ & EN $^{(1)}$ & NBR \\
\hline$g_{1}(x)$ & 4.81 & 5.55 & 5.53 \\
$g_{2}(x)$ & 2.12 & 2.82 & 2.84 \\
$g_{3}(x)$ & 3.36 & 3.74 & 3.72 \\
$g_{4}(x)$ & 1.54 & 2.44 & 2.26 \\
Number of strands & 48 & 40 & 40 \\
\hline
\end{tabular}

(1) Reliability indices from Caprani, Mayer and Siamphukdee [5]

by FORM, for the Australian (AS), European (EN) and the Brazilian (NBR) standards.

The reliability index for the four limit state equations for NBR were slightly below the values obtained for EN. This small difference occurs due to the bias factor of the bending moment generated by the traffic load model of each standard and the allowable tensile stress. As compared to the Australian standard, NBR has higher values for the reliability index because the bending moment generated by the Australian standard traffic load model has a low bias factor for the serviceability limit state situation (Capriani Mayer and Siamphukdee [5]).

The reliability index obtained by using equation $g_{4}(x)$ for the three standards did not reach the target reliability index of 2.9 provided by the European standard. Besides equation $\mathrm{g}_{4}(\mathrm{x})$, the AS does not meet the 2.9 value for equation $\mathrm{g}_{2}(\mathrm{x})$. Table 9 presents the annual target reliability indexes presented in the European standard and by the Joint Committee on Structural Safety (JCSS). The target reliability index of 2.9 for service limit state seem to be high.

The JCSS[13] proposes values for the target reliability index for the irreversible serviceability limit state. EN obtained values of the

\section{Table 9}

Literature annual target reliability indices for the different service limit state functions

\begin{tabular}{cc}
\hline Reference & $\beta_{\text {alvo }}$ \\
\hline EN1990:2002 - basis of structural design & 2.9 \\
JCSS 2000b (low relative cost of safety measure) & 1.3 \\
JCSS 2000b (moderate relative cost of safety measure) & 1.7 \\
JCSS 2000b (high relative cost of safety measure) & 2.3 \\
\hline
\end{tabular}

reliability index higher than 2.3 in all the four equations. NBR has three reliability indexes higher than 2.3 and, for equation $\mathrm{g}_{4}(\mathrm{x})$, this value was very close; AS does not meet the value 2.3 for equations $\mathrm{g}_{2}(\mathrm{x})$ and $\mathrm{g}_{4}(\mathrm{x})$.

These reliability indexes may be unconservative because in the loss of prestressing, the values of average and coefficient of variation recommended by the JCSS [14] seems to be high. These values were based on Naaman and Siriaksorn [19].

The four limit state equations studied were assumed to be perfect; that is, the model error was assumed as unitary since there is no study assessing the model error for the serviceability limit state of prestressed bridge guirders.

The reliability indexes were obtained through a design which sought a smaller number of tendons and the largest excentricity possible. The reduction in excentricity and the increase in the number of tendons may lead to other results.

\subsection{Analysis of sensitivity}

The sensitivity was obtained by deriving the first-order probability of failure estimate with respect to the design variables in standard normal space. This sensitivity is a linear measure and, therefore, it serves only as an approximation to the non-linear limit state equa-

\section{Table 10}

Sensibility analysis of random variables on annual serviceability reliability indices for each limit state function

\begin{tabular}{|c|c|c|c|c|}
\hline & $g_{1}(x)$ & $g_{2}(x)$ & $g_{3}(x)$ & $g_{4}(x)$ \\
\hline$\sigma_{c, \text { ato }}$ & - & $97.43 \%$ & - & - \\
\hline$\sigma_{\mathrm{c}, \text { ope }}$ & - & - & $95.37 \%$ & - \\
\hline$\sigma_{t, \text { ato }}$ & $29.41 \%$ & - & - & - \\
\hline$\sigma_{t, o p e}$ & & - & - & $7.07 \%$ \\
\hline $\mathrm{P}_{0}$ & $1.28 \%$ & $0.41 \%$ & $0.02 \%$ & $2.24 \%$ \\
\hline$e_{b}$ & $4.96 \%$ & $0.11 \%$ & $0.12 \%$ & $0.40 \%$ \\
\hline$A$ & $4.09 \%$ & $0.19 \%$ & $0.14 \%$ & $0.66 \%$ \\
\hline$W_{i, \text { ato }}$ & - & $0.19 \%$ & - & $0.04 \%$ \\
\hline$W_{\text {s.ato }}$ & $15.91 \%$ & - & $0.01 \%$ & \\
\hline$W_{i, \text { ope }}$ & - & - & - & $3.26 \%$ \\
\hline$W_{\mathrm{s}, \text { ope }}$ & - & - & $0.40 \%$ & - \\
\hline$\Delta \mathrm{P}_{\mathrm{i}}$ & $2.52 \%$ & $0.79 \%$ & - & - \\
\hline$\Delta \mathrm{P}_{\text {inf }}$ & - & - & $0.30 \%$ & $29.04 \%$ \\
\hline$M_{\text {pre }}$ & $41.83 \%$ & $0.88 \%$ & $1.27 \%$ & $4.91 \%$ \\
\hline$M_{\text {laje }}$ & - & - & $0.83 \%$ & $3.20 \%$ \\
\hline $\mathrm{M}_{\mathrm{cp}}$ & - & - & $0.30 \%$ & $4.65 \%$ \\
\hline$M_{T}$ & - & - & $1.24 \%$ & $44.53 \%$ \\
\hline
\end{tabular}


tions and for non-normal probability distributions. This information is very important, as it allows reducing the dimension of the problem by eliminating unimportant variables (Melchers and Beck [18]). Table 10 presents the analysis of sensitivity for the four limit state equations.

The analysis of sensitivity shows that for limit state equation $g_{1}(x)$, the random variables bending moment due to weight of the prestressed " $u$ " beam $\left(M_{\text {pre }}\right)$, allowable tensile stress during prestressing $\left(\sigma_{\text {tato }}\right)$ and elastic section modulus at the upper fiber during prestressing $\left(\mathrm{W}_{\mathrm{s}, \mathrm{ato}}\right)$ have a greater contribution to the probability of failure.

During prestressing, the upper fibers at mid-span stressed because the moment of prestressing is greater than the weight of the prestressed beam, making random variable $M_{\text {pre }}$ be important for the probability of failure.

For limit state equations $g_{2}(x)$ and $g_{3}(x)$, only the random variables of the allowable stresses are of importance for the analysis of reliability. The result of the analysis of sensitivity for these two equations is not surprising because the allowable stresses play an important role in the design.

Limit state equation $g_{4}(x)$, which has the lowest reliability index, has great sensitivity to the random variables of total loss of prestressing force $\left(\Delta \mathrm{P}_{\text {inf }}\right)$ and traffic load bending moment $\left(\mathrm{M}_{\mathrm{TT}}\right)$. The allowable tensile stress for this limit state equation has little sensitivity as compared to the two other aforementioned variables.

\section{Conclusions}

The analysis of reliability allows design standards to establish a minimum safety level, and analysts to assess the safety performance of structures designed according to these standards. The reliability indexes obtained herein show that the Brazilian standard has a safety level similar to that of the European standard and greater than the Australian standard.

The random variables bending moment due to weight of the precast " $u$ " beam $\left(\mathrm{M}_{\text {pre }}\right)$, the allowable tensile stress during prestressing $\left(\sigma_{t, \text { ato }}\right)$, the bending resistance modulus of the upper fiber during prestressing $\left(\mathrm{W}_{\mathrm{s}, \text { ato }}\right)$, the allowable compressive stress during prestressing $\left(\sigma_{c, \text { ato }}\right)$, the admissible compressive stress in operation $\left(\sigma_{c, o p e}\right)$, the total losses of prestressing strength $\left(\Delta \mathrm{P}_{\text {inf }}\right)$ and the bending moment the traffic load model $\left(\mathrm{M}_{\mathrm{TT}}\right)$ showed the largest influences in reliability analysis results.

The results of this work are for the maximum moment at the midspan; there may be other more critical cases in which the reliability index may be lower.

\section{References}

[1] Al-Harthy, A. S., e D. M. Frangopol. 1994. Reliability Assessment of Prestressed Concrete Beams. Journal of Structural Engineering 120 (1): 180-199.

[2] ASSOCIAÇÃO BRASILEIRA DE NORMAS TÉCNICAS. Projeto de estruturas de concreto - Procedimento - NBR 6118, Rio de Janeiro, 2014

[3] ASSOCIAÇÃO BRASILEIRA DE NORMAS TÉCNICAS. Carga móvel rodoviária e de pedestres em pontes, viadutos, passarelas e outras estruturas - NBR 7188, Rio de Janeiro, 2013.
[4] Bartlett, F. M., and J. G. MacGregor. 1996. Statistical Analysis of the Compressive Strength of concrete in Structures. ACI Materials Journal 93 (2): 158-168.

[5] Caprani, C. C., Mayer M. M. e Siamphukdee K. Reliability analysis of a Super-T prestressed concrete girder at serviceability limit state to AS 5100:2017, Australian Journal of Structural Engineering, 18:2, 60-72, DOI: 10.1080/13287982.2017.1332843

[6] Du, J. S., and F. T. K. Au. 2005. Deterministic and Reliability Analysis of Prestressed Concrete Bridge Girders: Comparison of the Chinese, Hong Kong and AASHTO LRFD Codes. Structural Safety 27 (3): 230-245. doi: 10.1016/j.strusafe.2004.10.004.

[7] European Committee for Standardization. 2005. EN 1990:2002. Eurocode - Basis of structural design. Eurocode 0 . Brussels: European Committee for Standardization.

[8] European Committee for Standardization. 2010. EN 19912:2003. Eurocode 1 - Action on Structures - Part 2: Traffic Loads on Bridges. Brussels: European Committee for Standardization.

[9] Foster, S. J., M. G. Stewart, M. Loo, M. Ahammed, e V. Sirivivatnanon. 2016. Calibration of Reinforced Concrete Structures Standard AS3600 Part I: Statistical Analysis of Material Properties and Model Error. Australian Journal of Structural Engineering 17 (4): 242-253. Taylor \& Francis. doi: 10.1080/13287982.2016.1246793.

[10] Gilbertson, C.G. e Ahlborn, T.M. 2004. A Probabilistic Comparison of Prestress Loss Methods in Prestressed Concrete Beams. PCl Journal: 52-69.

[11] Hueste, M. B. D., P. Chompreda, D. Trejo, D. B. H. Cline, e P. B. Keating. 2004. Mechanical Properties of Highstrength Concrete for Prestressed Members. ACI Structural Journal 101 (4): 457-465.

[12] Hwang, E. S., S. H. Nguyen, e Q. H. Nguyen. 2014. Development of Serviceability Limit State Design Criteria for Stresses in Prestressed Concrete Girders. KSCE Journal of Civil Engineering 18 (7): 2143-2152. doi: 10.1007/ s12205-014-1426-x.

[13] JCSS. 2000a. Probabilistic Model Code - Part 3. Joint Committee on Structural Safety.

[14] JCSS. 2000b. Probabilistic Model Code - Part 1. Joint Committee on Structural Safety.

[15] Jovem, T. P. Estudo Analítico e Numérico de Repartição de Carga em Tabuleiros de Pontes Retas com Longarinas Múltiplas de Concreto Armado. 2017. 152 f. Dissertação (Mestrado) - Curso de Programa de Pós-graduação em Engenharia Civil, Centro de Tecnologia, - Universidade Federal do Rio Grande do Norte, Natal, 2017.

[16] Kasyznska, M., e A. S. Nowak. 2005. Target Reliability for Design and Evaluation of Bridges. Fifith International Conference on Bridge Management, 401-408. Guildford: Thomas Telford.

[17] Luchi, L. A. R., 2006. Reavaliação do trem-tipo à luz das cargas reais nas rodovias brasileiras. Tese de doutorado. EPUSP, São Paulo, SP, Brasil.

[18] Melchers, R. E. e Beck, A. T. 2017. Structural Reliability Analysis and Prediction. Chichester: Wiley. 
[19] Naaman, A. E.; Siriaksorn, A. Reliability of Partially Prestressed Beams at Serviceability Limit States. Pci Journal, v. 27 , n. 6, p.66-85, 1 nov. 1982. Precast/Prestressed Concrete Institute. http://dx.doi.org/10.15554/ pcij.11011982.66.85

[20] Nowak, A. S., H. Nassif, and L. DeFrain. Effect of Truck Loads on Bridges. Journal of Transportation Engineering, Vol. 119, No. 6, 1993, pp. 853-867.

[21] Nowak, A. S., e K. R. Collins. 2013. Reliability of Structures. 2nd ed. Boca Raton, FL: CRC Press.

[22] Nowak, A. S., C. H. Park, e J. R. Casas. 2001. Reliability Analysis of Prestressed Concrete Bridge Girders: Comparison of Eurocode, Spanish Norma IAP and AASHTO LRFD. Structural Safety 23 (4): 331-344. doi: 10.1016/ S0167-4730(02)00007-3.

[23] Nowak, A. S., M. M. Szersen, E. K. Szeliga, A. Szwed, e P. J. Podhorecki. 2008. Reliability-based Calibration for Structural Concrete, Phase 3. Portland Cement Association 2849: 110.

[24] OBrien, E. J., F. Schmidt, D. Hajializadeh, X. Y. Zhou, B. Enright, C. C. Caprani, S. Wilson, E. Sheils. 2015. A Review of Probabilistic Methods of Assessment of Load Effects in Bridges. Structural Safety 53: 44-56. Elsevier Ltd. doi: 10.1016/j.strusafe.2015.01.002.

[25] O'Brien, E.J. and Enright, B. Modeling same-direction twolane traffic for bridge loading. Structural Safety, No. 33, pp. 296-304, 2011.

[26] O'Connor, A., e I. Enevoldsen. 2007. Probability-based Bridge Assessment. Bridge Engineering 160 (BE3): 129 137. doi: $10.1680 /$ bren.2007.160.3.129.

[27] Portela, E. L. et al . Single and multiple presence statistics for bridge live load based on weigh-in-motion data. Rev. IBRACON Estrut. Mater., São Paulo, v. 10, n. 6, p. 1163-1173, Nov. 2017. Available from <http:// www.scielo.br/scielo.php?script=sci_arttext\&pid=S198341952017000601163\&Ing=en\&nrm=iso $>$. access on 04 Apr. 2018. http://dx.doi.org/10.1590/s198341952017000600002.

[28] Rakoczy, A. M., e A. S. Nowak. 2013. Reliability-based Sensitivity Analysis for Prestressed Concrete Girder Bridges. PCl Journal 59 (4): 129-130.

[29] Sivakumar, B., M. Ghosn, and F. Moses. NCHRP Report 683; Protocols for Collecting and Using Traffic Data in Bridge Design. Transportation Research Board of the National Academies, Washington, DC, 2011.

[30] Stucchi, F. R., \& Luchi, L. A. R. e. (2015). Real road load compared to standard load for Brazilian bridges. Proceedings of the ICE - Bridge Engineering, 168(3), 245-258. https://doi.org/10.1680/bren.13.00028

[31] STUCCHI, F. R.; SANTOS, S. H. C.Evaluation of the Safety Criteria of Brazilian Standard NBR 6118 Based on Reliabilty Analyses. In: Joint IABSE fib Conference: Codes in Structural Engineering, Dubrovinik, 2010.

[32] STUCCHI, F. R.; SANTOS, S. H. C. Reliability based comparison between ACI 318-05 and NBR 6118. Revistalbracon de Estruturas, São Paulo, v. 3, n. 2, 2007.

[33] Sykora, M., D. Diamantidis, M. Holicky, e K. Jung. 2017. Target Reliability for Existing Structures Considering Eco- nomic and Societal Aspects. Structure and Infrastructure Engineering 13 (1): 181-194. Taylor \& Francis. doi: 10.1080/15732479.2016.1198394. 